\title{
International Journal of Applied Microbiology and Biotechnology
} Research

www.bluepenjournals.org/ijambr

\section{Cultivation-dependent and -independent approaches for determining the distribution of \\ Fusarium oxysporum f. sp. cubense tropical race 4 in soil of banana plantations in Côte d'Ivoire}

Toualy Serge Ouina ${ }^{1,3 \star}$, Voko Bi Rosin Don Rodrigue1, Stéphanie Gente ${ }^{2}$, David Garon², Jean-Philippe Rioult ${ }^{2}$, Jean-Michel Panoff ${ }^{3}$ and Marina Koussémon-Camara ${ }^{4}$

1'Laboratory of Agrovalorisation, Department of Biochemistry-Microbiology, University Jean Lorougnon Guédé, BP 150 Daloa, Côte d'Ivoire.

2University of Caen Normandy, Food, Bioprocess, Toxicology, Environments (Team 4651) - Environmental Toxicology, Aerial Environments and Cancer, 14000 Caen, France.

${ }^{3}$ Food, Bioprocess, Toxicology, Environments (Team 4651) - Food Matrix and Microbiota - Campus 1, Institute for Fundamental and Applied Biology, University of Caen Normandy, Esplanade de la Paix, 14032 Caen cedex 5, France.

${ }^{4}$ Laboratory of Biotechnology and Food Microbiology, Faculty of Sciences and Food Technology,

Nangui Abrogoua University, 02 BP 801 Abidjan 02, Cote d'Ivoire.

Article History

Received 30 July, 2021

Received in revised form 26

August, 2021

Accepted 31 August, 2021

Keywords:

Fusarium wilt,

Banana,

Soil,

Foc TR4,

Côte d'Ivoire.

Article Type:

Full Length Research Article

\begin{abstract}
Banana Fusarium wilt caused by Fusarium oxysporum f. sp. cubense tropical race 4 (Foc TR4), is a worrying destructive disease affecting banana plantations with devastating effects on food safety and economy of many tropical countries. There is few information about this disease in Côte d'Ivoire. This study was aimed at assessing the distribution of Foc TR4 in banana plantations of the Lôh-Djiboua region (Côte d'Ivoire) and then finding the most sensitive research methods of Foc TR4 in the soil of these plantations. Foc TR4 was searched for in soils of 8 banana plantations through culture-dependent (CDMA) and culture-independent molecular approaches (CIMA). CDMA consisted of the isolation of $F$. oxysporum from culture media and subjecting it to molecular confirmation tests at subspecies level. CIMA consisted of searching for Foc TR4 directly from soil samples with molecular probes. Molecular detection limit of Foc TR4 was also searched for in the mix: i) Foc TR4 DNA and ultra-pure water and ii) Foc TR4 DNA and pool of DNA from Foc TR4 free soil. Foc TR4 was found in 5 plantations. For 16 of the soil samples analyzed, CDMA showed that 8 samples belonging to 5 plantations harboured Foc TR4 whereas with CIMA, Foc TR4 were isolated from 3 samples belonging to 2 plantations. FocTR4 DNA was detected in the soil by polymerase chain reaction (PCR) from $73 \pm 6.02 \mathrm{ng}$. The combination of CDMA and CIMA led to a better estimate of Foc TR4 distribution. CDMA was more sensitive for detecting Foc TR4 in the soil of the plantations investigated.
\end{abstract}

(C)2021 Blue Pen Journals Ltd. All rights reserved

\section{INTRODUCTION}

Banana (Musa spp.) is one of the world's most important crops owing to its economic and food interest. It is much appreciated in many tropical countries. For instance, plantain being the $3^{\text {rd }}$ staple food after rice and yam in Côte
d'Ivoire is a major ingredient of various food such as "foutou", "foufou", "alloco", "chips" assuring food diversification and security. Dessert banana which is in priority intended for exportation, represents a driving 
force in economy. Banana sector accounts for 5 to $8 \%$ of agricultural GDP (FIRCA, 2014).

In all banana growing areas, cultivation of banana, is unfortunately threatened by bacteria, viruses, fungi, nematodes and weevils. Among these attacks, fungi have been for a long time a growing threat and lead to severe affections of the leaves, stems, fruits and roots, resulting in significant yield reductions (Stover, 1959; Viljoen, 2002; De Bellaire et al., 2010; Dita et al., 2018). Fusarium wilt is a serious fungal disease that affects banana plant. It is caused by the soil-borne fungus Fusarium oxysporum $\mathrm{f}$. sp. cubense (Foc) and is responsible of constraints on banana production causing serious economic losses worldwide (Ploetz, 2015; Dita et al., 2018). Based on the susceptibility to reference host cultivars, Foc can be divided into four physiological races of which three caused banana diseases. Race 1 caused the epidemics on Gros Michel (AAA) and Manzano/Apple/Latundan (Silk, AAB). Race 2 affects cooking bananas of the Bluggoe (ABB) subgroup and race 4 infects almost all cultivars including "Dwarf Cavendish" (AAA) as well as the hosts of race 1 and race 2 (Lassoudière, 2007; Lin et al., 2013; Sutherland et al., 2013). Race 3 infects Heliconia spp. but it is no longer considered as part of Foc (Ploetz, 2005). Race 4 has been split into subtropical race 4 , which affects "Cavendish" and races 1 and 2 suscepts in the subtropics, and tropical race 4 , which affects many of the same cultivars as subtropical race 4 in the tropics when diseasepredisposing conditions are absent (Ploetz, 2015). Furthermore, owing to confusions and inaccuracies of the race structure often happening in delineating strains of Foc, vegetative compatibility has been implemented as a strategy to categorize the pathogen. A total of 24 vegetative compatibility groups (VCGs) have been identified for Foc. Tropical race 4 is designated as VCG $01213 / 16$ and subtropical race 4 belong to VCGs 0120 , 0121, 0122, 0129 and 01211 (Dita et al., 2010; Mostert et al., 2017). Fusarium wilt, also known as Panama disease, affected several banana plantations in Australia, Taiwan, Philippines, India, Mozambique (Pegg et al., 1996; Ploetz, 2015; Viljoen et al., 2020) and South Africa (Viljoen, 2002).

Foc TR4 is a soil fungus which starts its infection process in banana by the roots. Indeed, from the soil, it travels through the roots, rhizome, and up the pseudostem. It reaches the outside of the pseudostem by 24 days post infection. At this stage, the plants show severe symptoms or necrosis (Ploetz, 2000; Warman and Aitken, 2018). The main dispersal modes of this fungus are the transport of plant material, soil and water runoff from contaminated areas to other areas (Daly and Walduck, 2006; PerezVicente et al., 2014). The rapid dispersion of Foc TR4 is

${ }^{*}$ Corresponding author. E-mail: ouitoualy@yahoo.fr. Tel: (+225) 0777849878 / 0505674687. one of the factors that render Fusarium wilt, one of the most destructive diseases. Management of this disease is restricted to exclude the pathogen from non-infected area and use resistant cultivars where Foc TR4 is established (Ploetz, 2015). Thus, an efficient management is conditioned by a diagnostic of the fungus in a nonexanimated areas.

According to Kra et al. (2011), a few cases of Fusarium wilt were discovered in 2006 on some banana cultivars "Grand Nain" and "Corn 1" in the south of Côte d'Ivoire and since that time, little is known about occurrence of this disease in other Ivorian banana production areas. The region of Lôh-Djiboua (Côte d'Ivoire) contributes alongside high banana production areas in Côte d'Ivoire, to supply markets across the country. In addition, one of the goals of the Ivorian authorities, is to make this region an attractive future agricultural pole (Ouina et al., 2020). This present study aimed to determine the distribution of Foc TR4 in the soil of some banana plantations in the region of Lôh-Djiboua. Specifically, two approaches, culturedependent and independent methods were used in other to circumvent possible bias related to antagonism that may exist between micro-organisms during the cultivation step of soil samples.

\section{MATERIALS AND METHODS}

\section{Characteristics of study site}

The field phase of this study was conducted in 2016 in the region of Lôh-Djiboua, located in the West Central of Côte d'Ivoire. The climate of this region is of the transitional equatorial type, which combines two rainy seasons with two dry seasons. The average annual rainfall and temperature are respectively between 1200 and $1600 \mathrm{~mm}$ and between 20 and $35^{\circ} \mathrm{C}$ around. Soils are generally ferrallitic, highly desaturated in the south (PRICl, 2016). The localities investigated in this study were Divo and Lakota, with respective geographical coordinates $\left(5^{\circ} 49^{\prime} 59\right.$

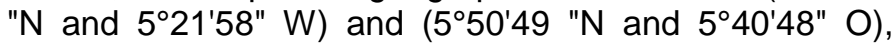
determined with the aid of Google Earth 7.1.5.1557 release (Google, Mountain View, California/USA).

\section{Soil sampling in banana plantations}

Soil sampling was carried out during the month of August 2016 in eight banana plantations of which four located in the locality of Divo (B1, B2, B3 and B4) and four in the locality of Lakota (B5, B6, B7 and B8) following Ouina et al. (2020) with some modifications. The minimum distance between two bananas plantations were about $10 \mathrm{~km}$. Among these eight banana plantations, six were of plantain type and two of dessert banana type. In each 
locality, three banana plantations of plantain type and one of dessert type were chosen. First, two groups of four banana plants approximately located $80 \mathrm{~m}$ about from each other, were formed in each banana plantation. A group is defined as a $8 \mathrm{~m}$ diameter circular zone in which there are banana trees. Banana plants chosen in a group were spaced at least $4 \mathrm{~m}$ about apart from each other. Within a group and in a radius of $0.5 \mathrm{~m}$ around the foot of each chosen banana tree, the soil surface was cleared of plant and animal debris using a hoe. At a depth of 15 to 20 $\mathrm{cm}, 15 \mathrm{~g}$ of soil adhering to the roots were taken by hand with gloves. The mass of soil from each banana plant were homogeneously mixed and the resulting quantity $(60 \mathrm{~g})$ of soil constitute a soil sample. In each banana plantation, two soil samples from each group codified $S 1$ and $S 2$ were taken, packaged in sterile bag and kept in a cooler with ices. A total of 16 soil samples were collected and sent to the laboratory for analysis.

\section{Research of $F$. oxysporum f. sp. cubense tropical race 4 (Foc TR4)}

The fungus $F$. oxysporum f. sp. cubense tropical race 4 (Foc TR4) was searched from soil samples through the culture-dependent and culture-independent molecular approaches as described below according to Ouina et al. (2020).

\section{Culture-dependent molecular approach}

The culture-dependent molecular approach consisted of isolating $F$. oxysporum on culture media and submitting these isolates to molecular confirmation tests at the level of subspecies (Foc TR4).

Cultivation of fungi: For implementing this step, soil samples collected from banana farm of the study site were cultivated on the culture media Potato Dextrose Agar (PDA), Cristomalt (CM) and Cristomalt+lithium (6 g/L) (CML), through the technique of soils plates (Warcup, 1950). Briefly, amounts of 5 to $10 \mathrm{mg}$ of each soil sample collected were weighed using a precision balance (Sartorius CP 225D, AG Germany) and placed in Petri dishes without ergot. Twenty-five milliliters of PDA, CM or CML medium, previously prepared and kept in supercooling at 45 to $50^{\circ} \mathrm{C}$, were added thereto. Weighed soil was immediately dispersed in each culture medium with gentle stirring until solidification. Petri dishes were incubated at $25^{\circ} \mathrm{C}$ for $72 \mathrm{~h}$ to 7 days. Colonies like $F$. oxysporum on the basis of their macroscopic and microscopic characters (Domsch et al., 1980) observed on each medium, have been picked individually on the PDA medium and incubated in the same conditions as previously.

DNA extraction: DNA was extracted from mycelium of presumptive colonies of $F$. oxysporum obtained on culture media by using the "NucleoSpin Plant II" kit (MacheryNagel, Hœrdt, France). The protocol of this kit was observed with some modifications as described by Seguin et al. (2014). Briefly, about $200 \mathrm{mg}$ of the mycelium of the fungal culture were lightly scraped off with a spatula and placed in a $2 \mathrm{~mL}$ "safe lock" Eppendorf tube containing 1 $\mathrm{g}$ of glass beads ( $1 \mathrm{~mm}$ diameter) and 2 glass beads of 5 $\mathrm{mm}$ diameter. A quantity of $400 \mu \mathrm{L}$ of the PL1 buffer was deposited in the "safe lock" tube, then the mixture was placed in a Tissue Lyser (Qiagen) for 15 minutes at $20 \mathrm{~Hz}$. After grinding the mycelium using the tissue lyser and incubation for $10 \mathrm{~min}$ at $65^{\circ} \mathrm{C}, 400 \mu \mathrm{L}$ of chloroform and 20 $\mu \mathrm{L}$ of proteinase $\mathrm{K}$ were deposited in the tube. The aqueous phase of the mixture manually homogenized for $30 \mathrm{~s}$ and centrifuged for $5 \mathrm{~min}$ at $13400 \mathrm{rpm}$ was filtered on a violet filtration column. The filtrate was retained and mixed with $450 \mu \mathrm{L}$ of PC buffer. This last mixture was filtered on a green column which retains the DNA. After washing the green column with $400 \mu \mathrm{L}$ of PW1 buffer and twice with 700 and $200 \mu \mathrm{L}$ of PW2 buffer, the fixed DNA was eluted with $100 \mu \mathrm{L}$ of PE buffer previously heated at $65^{\circ} \mathrm{C}$. The extracted DNA were quantified using the spectrophotometer (Nanodrop 2000). Their purities were checked by the ratio $A_{260 / 280}$ (about 1.8 for non-contamined DNA) and by assessing their ability of migrating on a $1 \%$ (w/v) agarose gel (Zhang et al., 2011).

Amplification: Extracted DNA from F. oxysporum were amplified by PCR by using universal primers set ITS 1 (TCCGTAGGTGAACCTGCGG) and ITS 4 (TCCTCCGCTTATTGATATG), which target the ITS region of ribosomal DNA, and specific primers set Foc TR4-F (CACGTTTAAGGTGCCATGAGAG) and Foc TR4R (CGCACGCCAGGACTGCCTCGTGA) targeting IGS region of ribosomal DNA (Dita et al., 2010; Seguin et al., 2014). The primers ITS $1 /$ ITS 4 and Foc TR4-F/Foc TR4$\mathrm{R}$, stood respectively for the confirmation of species $F$. oxysporum and the identification of sub-species Foc TR4. Each PCR reaction mixture contained $100-500 \mathrm{ng}$ of genomic DNA, 100 pmol of each of primers ITS 1 and ITS 4 or Foc TR4-F and Foc TR4-R (Eurogentec, Seraing, Belgique), $0.25 \mathrm{mM}$ of dNTP, reaction buffer Taq DNA Polymerase $10 \mathrm{X}$ with $\mathrm{MgCl}_{2} 25 \mathrm{mM}$ and $2.5 \mathrm{U}$ of AmpliTaq Gold DNA Polymerase (Applied Biosystems, Branchburg, NJ, USA) in a final volume of $50 \mu \mathrm{L}$. PCR were carried out using the following protocol: (i) $95^{\circ} \mathrm{C}$ for $4 \mathrm{~min}$ and 35 cycles of $95^{\circ} \mathrm{C}$ for $30 \mathrm{~s}, 52^{\circ} \mathrm{C}$ for $30 \mathrm{~s}$ and $72^{\circ} \mathrm{C}$ for $1 \mathrm{~min}$, followed by an additional extension time for $7 \mathrm{~min}$ at $72^{\circ} \mathrm{C}$ for primers ITS $1 /$ ITS 4 (Seguin et al., 2014) and (ii) $95^{\circ} \mathrm{C}$ for $10 \mathrm{~min}$ and $30 \mathrm{cycles}$ of $95^{\circ} \mathrm{C}$ for $1 \mathrm{~min}, 62^{\circ} \mathrm{C}$ for $1 \mathrm{~min}$ and $72^{\circ} \mathrm{C}$ for $1 \mathrm{~min}$, followed by an additional extension time for 10 min at $72^{\circ} \mathrm{C}$ for primers Foc TR4-F/Foc TR4-R (Dita et al., 2010). 
Table 1. DNA composition of PCR reaction medium for the research of molecular detection limit under different conditions.

\begin{tabular}{lccccccccccc}
\hline DNA composition & \multicolumn{10}{c}{ Amount of DNA (ng) } \\
\hline $\begin{array}{l}\text { Condition "ultra-pure water" } \\
\text { DNA of Foc TR4 }\end{array}$ & 0 & 10 & 20 & 30 & 40 & 50 & 60 & 70 & 80 & 90 & 100 \\
Condition "community DNA of soil" & & & & & & & & & & \\
DNA of Foc TR4 & 0 & 10 & 20 & 30 & 40 & 50 & 60 & 70 & 80 & 90 & 100 \\
Total soil DNA & 100 & 90 & 80 & 70 & 60 & 50 & 40 & 30 & 20 & 10 & 0 \\
\hline
\end{tabular}

Post-amplification analysis of DNA: The migration of PCR products were realized in a $1 \%(\mathrm{w} / \mathrm{v})$ agarose gel, which was stained with Midori green and visualized under UV light. Amplicons obtained with the primers set ITS 1/ITS 4 were sequenced and sequences were aligned using BLAST for the detection of $F$. oxysporum. For specific detection of Foc TR4, amplicons obtained with the primers set Foc TR4-F/Foc TR4-R had to present a 463 base pairs (bp) size (Dita et al., 2010).

\section{Culture-independent molecular approach}

The culture-independent molecular approach consisted of researching Foc TR4 directly from soil samples with molecular probes.

DNA extraction: DNA was extracted directly from soil samples by using the "NucleoSpin Soil" kit (MacheryNagel, Hœrdt, France). An amount of $350 \mathrm{mg}$ of sol was deposited in a $2 \mathrm{~mL}$ Eppendorf tube "NucleoSpin® Bead Tubes" containing ceramic beads and $700 \mu \mathrm{L}$ of SL 1 buffer were added thereto. The mixture homogenized for $5 \mathrm{~s}$, was added with $150 \mathrm{~mL}$ of buffer SX, then placed in a Tissue Lyser for $5 \mathrm{~min}$ at $20 \mathrm{~Hz}$. After grinding with Tissue Lyser and centrifugation for $2 \mathrm{~min}$ at $13400 \mathrm{rpm}$, the supernatant was added to $150 \mu \mathrm{L}$ of SL3 buffer. This mixture was homogenized for $5 \mathrm{~s}$, incubated for $5 \mathrm{~min}$ at 0 to $4^{\circ} \mathrm{C}$ and centrifuged for $1 \mathrm{~min}$ at $13400 \mathrm{rpm}$. The resulting supernatant was filtered through a red Nucleospin inhibitor removal column. The eluate supplemented with $250 \mu \mathrm{L}$ of buffer SB was homogenized for $5 \mathrm{~s}$ and the mixture was filtered on a green NucleoSpin column which retains the DNA. Four washes of the green NucleoSpin column were carried out using $500 \mu \mathrm{L}$ of SB buffer, $550 \mu \mathrm{L}$ of SW 1 and twice $700 \mu \mathrm{L}$ of SW2. The fixed DNA was eluted with 50 $\mu \mathrm{L}$ of the SE buffer. The extracted DNAs were quantified by spectrophotometer (Nanodrop 2000). Their purities and migration abilities on agarose gel (1\%) were verified (Zhang et al., 2011).

DNA extracted from soil samples were submitted to amplification and post-amplification analysis in the same conditions as the culture dependent approach.

\section{Determination of molecular detection limit of Foc TR4}

Molecular detection limit of Foc TR4 was assessed in two conditions: i) DNA of Foc TR4 mixed with diluted ultra-pure water and ii) DNA of Foc TR4 mixed with total DNA extracted from free Foc TR4 soil. These conditions (ultrapure water and community DNA extracted from soil) describe respectively the research of Foc TR4 without contaminants and in presence of contaminants in real environment. This is a first report about laboratory conditions or methods that can be used to evaluate the sensibility of PCR in detecting pathogen in soil.

\section{DNA of Foc TR4 diluted in ultra-pure water}

Different amounts of genomic DNA of Foc TR4 varying between 0 and 100 ng were defined and dissolved in ultrapure water (Table 1). Amplification by PCR were performed from each of these DNA amounts using specific primers Foc TR4-F/Foc TR4-R. After electrophoresis of these amplicons on a $1 \%(\mathrm{w} / \mathrm{v})$ agarose gel, which was stained with Midori green and visualized under UV light, the least amount of DNA of Foc TR4 detected were considered as detection limit of Foc TR4 when diluting in ultra-pure water. The different reactions of PCR were realized in the same conditions previously described in the research of Foc TR4.

\section{DNA of Foc TR4 mixed with total DNA from free Foc TR4 soil}

Different amounts of genomic DNA of Foc TR4 and total DNA from free Foc TR4 soil were defined between 0 and $100 \mathrm{ng}$, respectively for each type of DNA. Each quantity of DNA of Foc TR4 were mixed with a quantity of soil DNA to obtain total DNA amount of $100 \mathrm{ng}$ (Table 1). Every mix of DNA were submitted to the set of operations [amplification, electrophoresis on $1 \%(\mathrm{w} / \mathrm{v})$ agarose gel and visualization under UV light] indicated in the research of molecular detection limit of Foc TR4 in ultra-pure water. After analysis of different amplicons obtained, the DNA mix with the least amount of DNA of Foc TR4 that have been 

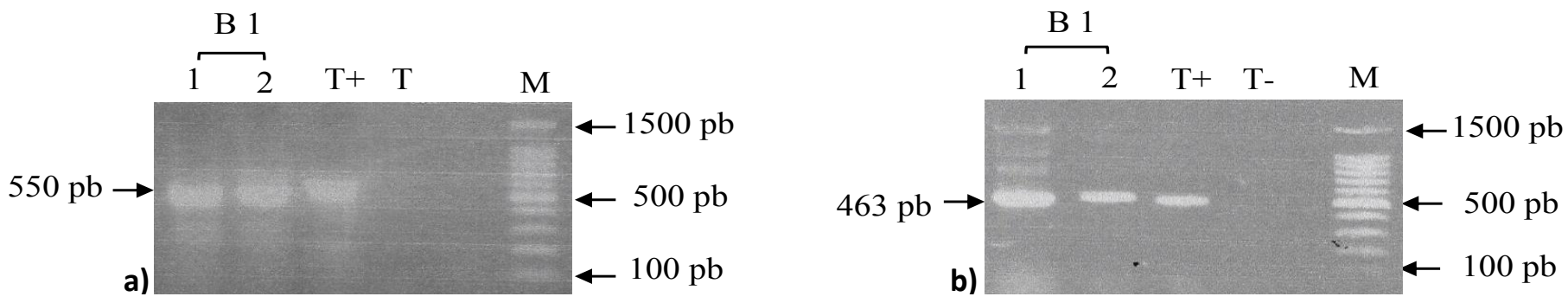

Figure 1. Electrophoresis gel of amplicons obtained with primers; $\mathbf{a}$, ITS 1/ITS 4; $\mathbf{b}$, Foc TR4-F/ Foc TR4-R of F. oxysporum isolated from banana plantation B1. Size of positive control T+ with ITS 1/ITS 4 and Foc TR4-F /Foc TR4-R are respectively 550 pb and 463 pb; B 1, Banana plantation 1; 1 and 2, DNA of $F$. oxysporum isolated after cultivation of soil samples $S 1$ and S2; T+ and T-, Positive and negative control; M, size marker.

Table 2. Contamination by F. oxysporum of soil samples from investigated banana plantations.

\begin{tabular}{|c|c|c|c|c|c|c|c|c|}
\hline & \multicolumn{8}{|c|}{ Banana plantations } \\
\hline & \multicolumn{4}{|l|}{ Lakota } & \multicolumn{4}{|l|}{ Divo } \\
\hline & B1 (P) & B2 (P) & B3 ${ }^{(P)}$ & B4 (D) & B5 ${ }^{(P)}$ & B6 (P) & B7 (P) & B8 (D) \\
\hline Soil sample in position S1 & + & + & - & - & - & + & + & + \\
\hline Soil sample in position S2 & + & - & - & + & - & + & + & + \\
\hline
\end{tabular}

B1 to B8: Banana plantation 1 to 8; (P)/(D): plantain type/dessert type; + or -: presence or absence of $F$. oxyporum in a given soil sample.

visualized under UV light was considered as detection limit of Foc TR4 when mixed with total soil DNA.

Three replicates were performed for each amount of DNA (Foc TR4 DNA and community DNA of soil) amplified under each condition.

\section{Statistical analyses}

The data collected during the research of molecular detection limit of Foc TR4 under each condition (DNA of Foc TR4 mixed with ultra-pure water and with DNA community extracted from soil) were entered using the Excel 2013 spreadsheet. The average and standard deviation values of Foc TR4 DNA threshold were determined using Statisca 7 software (StatSoft Inc, Tulsa, USA).

\section{RESULTS} Distribution of Foc TR4 in soil samples using culture-
dependent molecular approach

\section{Distribution of F. oxysporum in soil samples}

Different fungal species were isolated on the media PDA, $\mathrm{CM}$ and $\mathrm{CML}$ from soil samples $\mathrm{S} 1$ and $\mathrm{S} 2$ of each banana plantation. After identification of fungal isolates based on macroscopics and microscopics characteristics, it appears that of 16 soil samples tested, 10 harbour $F$. oxysporum so $62.5 \%$ of analyzed samples. In $75 \%$ of banana plantations (B1, B3, B5, B6, B7 and B8), when this species is found (or absent) in soil sample $\mathrm{S} 1$, it is also found (or absent) in soil sample S2 (Table 2).

\section{Molecular characteristics of F. oxysporum isolates}

Extraction of genomic DNA of $F$. oxysporum isolated on culture medium provided DNA concentrations between 231,4 et $577,3 \mathrm{ng} / \mu \mathrm{L}$. Amplification of ITS regions of these DNA generated amplicon sizes of $550 \mathrm{pb}$ for all samples tested (Figure 1). The sequencing of these amplicons resulted in sequences of 485 nucleotides which were compared with those in the data banks (via BLAST programme). Alignment statistics of these sequence are coverage and similarity rate of $100 \%$ for $F$. oxysporum (Sequence ID: GenBank KU863663.1) (Figure 2). Amplification of IGS regions provided amplicons of $463 \mathrm{pb}$ for 8 samples (Figure 1).

\section{Distribution of Foc TR4 in soil samples using culture- independent molecular approach}

The concentrations of genomic DNA extracted from soil 


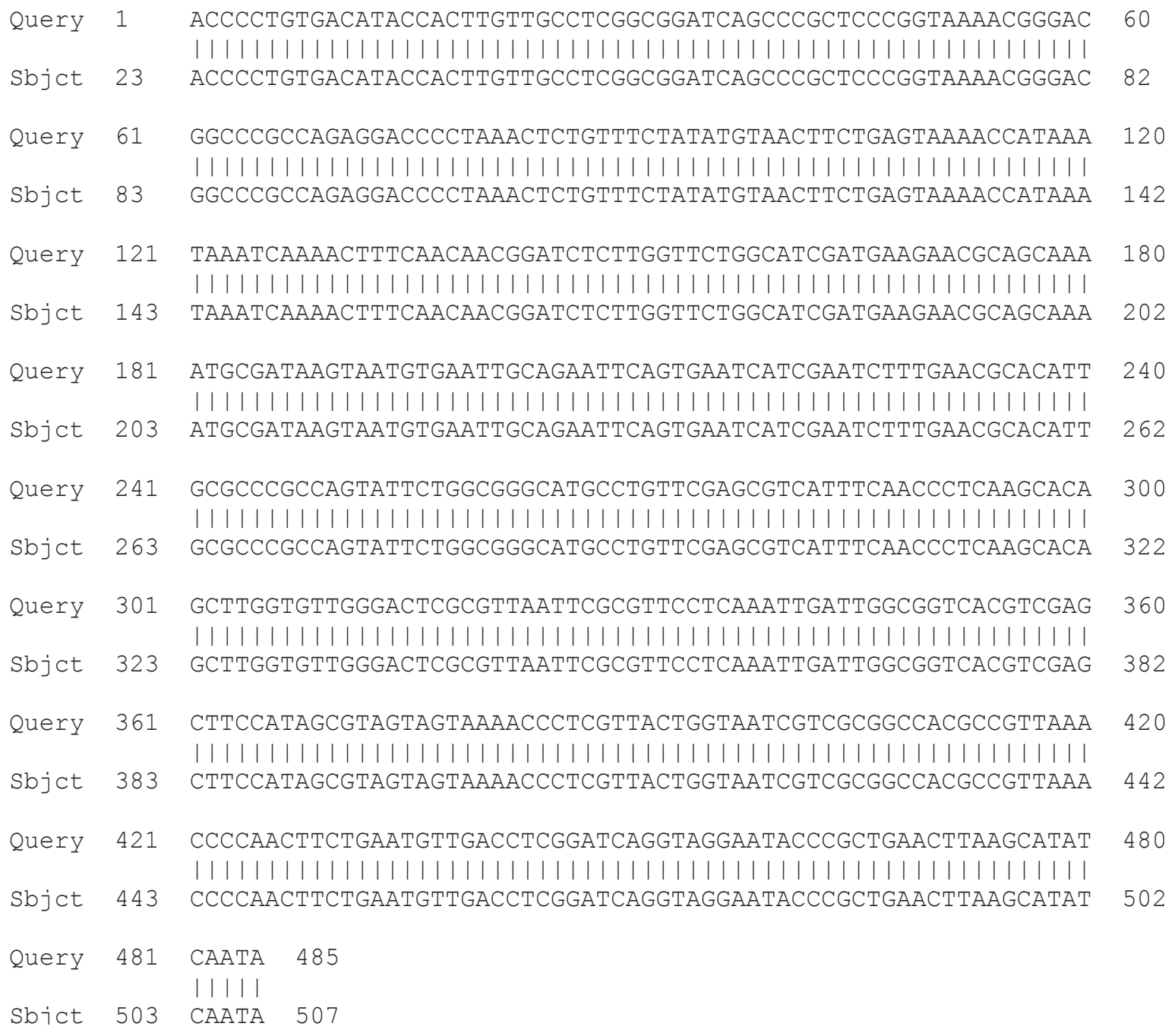

Figure 2. Alignment of nucleotide sequence of the rDNA ITS region of $F$. oxysporum isolated from the soil of banana plantation B1 (Sequence ID: GenBank KU863663.1).

samples S1 and S2 of each banana plantations were between 5 and $55 \mathrm{ng} / \mu \mathrm{L}$. Amplification of intergenic regions of ribosomal DNA with primers ITS $1 /$ ITS 4 and Foc TR4-F/Foc TR4-R showed respectively amplicons of $550 \mathrm{pb}$ and of $463 \mathrm{pb}$ from genomic DNA of certain soil samples (Figure 3). The Table 3 indicates the presence or absence of characteristics amplicons of Foc TR4 after amplification of DNA extracted from soil of banana plantations.

\section{Distribution of Foc TR4 in soil samples as a function of the two research methods}

A total of 16 soil samples of banana plantations covered in this study (so S1B1, S2B1, S1B2, S2B2, S1B3, S2B3, S1B4 et S2B4 for the locality of Lakota and S1B5, S2B5,
S1B6, S2B6, S1B7, S2B7, S1B8 et S2B8 for the locality of Divo), were analysed for the research of Foc TR4. Culturedependent molecular method showed that 8 soil samples (50\% of samples analyzed) such as S1B1, S2B1, S1B2, S2B4, S1B6, S2B6, S1B8 and S2B8 belonging to 5 plantations harbour Foc TR4 (so $62.5 \%$ of banana plantations studied). Concerning culture-independent molecular method, Foc TR4 were found in 3 soil samples S1B2, S1B6 and S2B6 belonging to 2 plantations (18.75\% of analyzed soil samples and $25 \%$ of banana plantations studied) (Table 4).

\section{Molecular detection limit of Foc TR4}

Data about assessment of molecular detection limit of Foc TR4 in the cases (i) DNA of Foc TR4 diluted in ultra- 


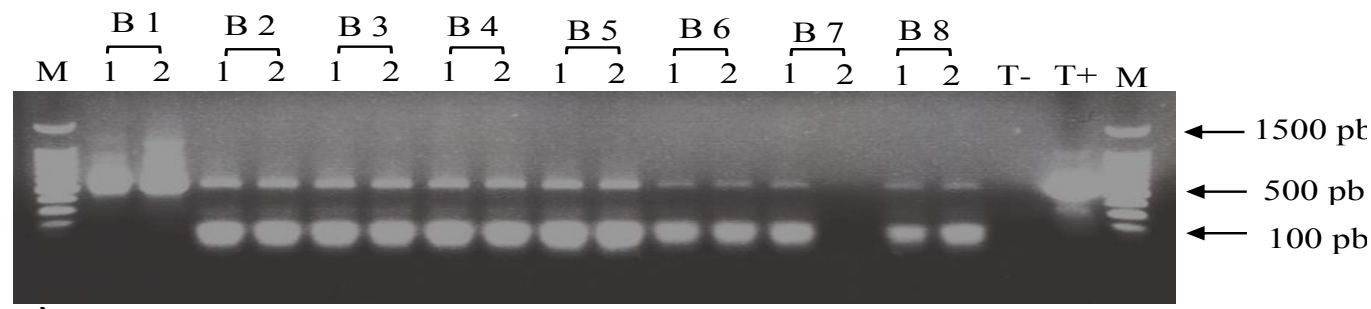

a)

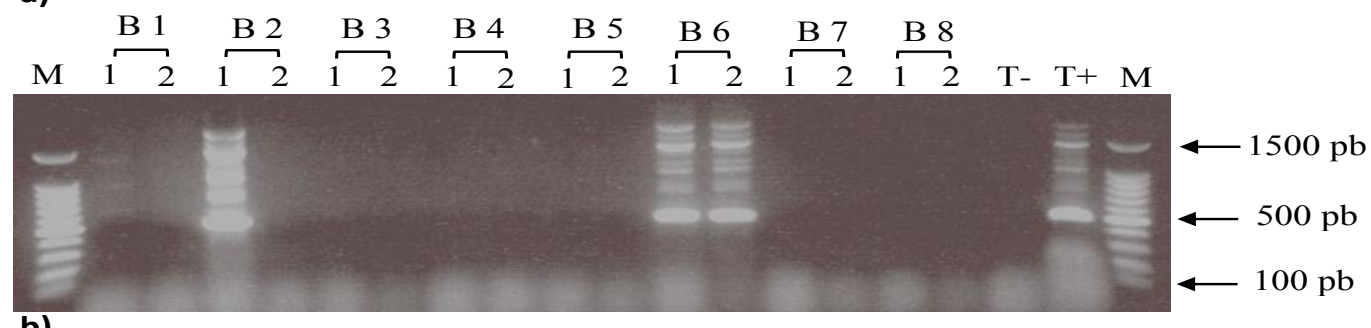

b)

Figure 3. Electrophoresis gels of amplicons obtained with a) ITS 1/ITS 4 and b) Foc TR4-F/Foc TR4-R [Size of positive control T+ with ITS 1/ITS 4 and Foc TR4-F /Foc TR4-R are respectively 550 pb and 463 pb; B1 to B8, Banana plantation 1 to 8 ; 1 and 2, DNA extracted from soil samples 1 and 2; T+ and T-, positive and negative; $\mathbf{M}$, size marker.

Table 3. Characteristics amplicons of Foc TR 4 after PCR from soils of banana plantations.

\begin{tabular}{|c|c|c|c|c|c|c|c|c|}
\hline & \multicolumn{8}{|c|}{ Banana plantations } \\
\hline & \multicolumn{4}{|c|}{ Lakota } & \multicolumn{4}{|c|}{ Divo } \\
\hline & B1 (P) & B2 ${ }^{(P)}$ & B3 ${ }^{(P)}$ & B4 (D) & B5 (P) & B6 (P) & B7 (P) & B8 (D) \\
\hline \multicolumn{9}{|c|}{ Amplicon of $550 \mathrm{pb}$ (primers ITS 1/ITS 4) } \\
\hline DNA extracted from soil sample S1 & + & + & + & + & + & + & + & + \\
\hline DNA extracted from soil sample S2 & + & + & + & + & + & + & - & + \\
\hline \multicolumn{9}{|c|}{ Amplicon of $463 \mathrm{pb}$ (primers Foc TR4-F/Foc TR4-R) } \\
\hline DNA extracted from soil sample $\mathrm{S} 1$ & - & + & - & - & - & + & - & - \\
\hline DNA extracted from soil sample S2 & - & - & - & - & - & + & - & - \\
\hline
\end{tabular}

B1 to B8: Banana plantation 1 to 8 ; (P)/(D): plantain type/ dessert type; + or - : presence or absence of size amplicons of 550 pb or 463 pb after amplification of DNA extracted from a given soil sample.

Table 4. Comparative balance sheet of research methods of $F$. oxysporum f. sp. cubense tropical race 4 (Foc TR4) in the soil of banana plantations studied.

\begin{tabular}{|c|c|c|c|c|c|c|c|c|c|c|c|c|c|c|c|c|}
\hline \multirow{2}{*}{$\begin{array}{l}\text { Banana plantations } \\
\text { Soil samples }\end{array}$} & \multicolumn{2}{|c|}{ B1 ${ }^{(P)}$} & \multicolumn{2}{|c|}{ B2 (P) } & \multicolumn{2}{|c|}{ B3 ${ }^{(P)}$} & \multicolumn{2}{|c|}{ B4 (D) } & \multicolumn{2}{|c|}{ B5 (P) } & \multicolumn{2}{|c|}{$B 6^{(P)}$} & \multicolumn{2}{|c|}{ B7 ${ }^{(P)}$} & \multicolumn{2}{|c|}{$\mathrm{B} 8^{(\mathrm{D})}$} \\
\hline & S1 & S2 & S1 & S2 & S1 & S2 & S1 & S2 & S1 & S2 & S1 & S2 & S1 & S2 & S1 & S2 \\
\hline \multicolumn{17}{|l|}{ Methods } \\
\hline $\begin{array}{l}\text { Culture-dependent } \\
\text { molecular approach }\end{array}$ & + & + & + & - & - & - & - & + & - & - & + & + & - & - & + & + \\
\hline $\begin{array}{l}\text { Culture-independent } \\
\text { molecular approach }\end{array}$ & - & - & + & - & - & - & - & - & - & - & + & + & - & - & - & - \\
\hline \multicolumn{17}{|c|}{ Banana plantations contaminated by Foc TR4 } \\
\hline $\begin{array}{l}\text { Culture-dependent } \\
\text { molecular approach }\end{array}$ & \multicolumn{16}{|c|}{$\mathrm{B} 1, \mathrm{~B} 2, \mathrm{~B} 4, \mathrm{~B} 6$ and $\mathrm{B} 8$} \\
\hline $\begin{array}{l}\text { Culture-independent } \\
\text { molecular approach }\end{array}$ & \multicolumn{16}{|c|}{ B2 and B6 } \\
\hline
\end{tabular}

B1 to B8: Banana plantation 1 to 8; (P)/(D): plantain type/ dessert type; + or -: presence or absence of Foc TR4 in a given banana plantation. 


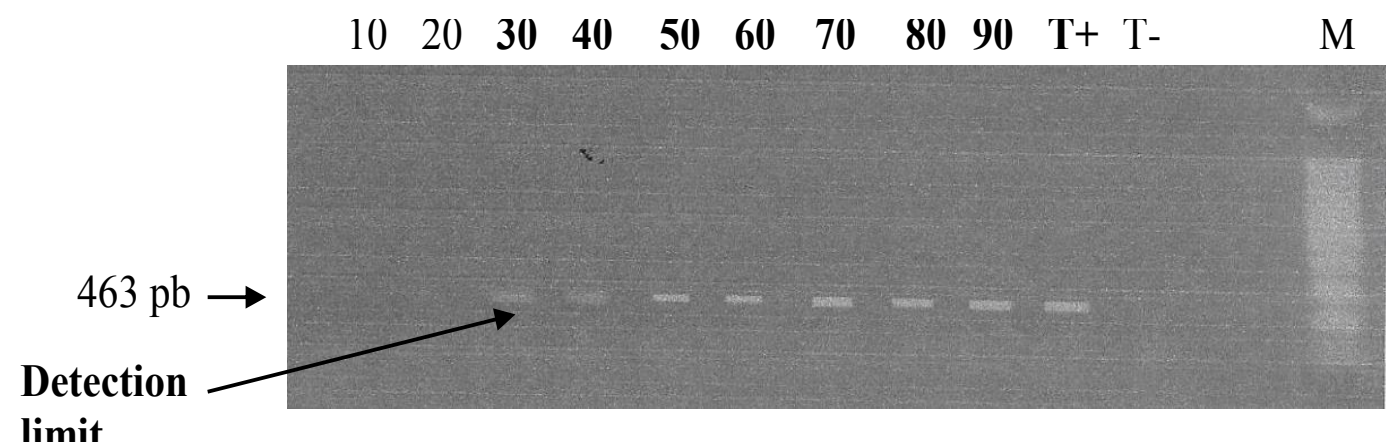
limit

a)

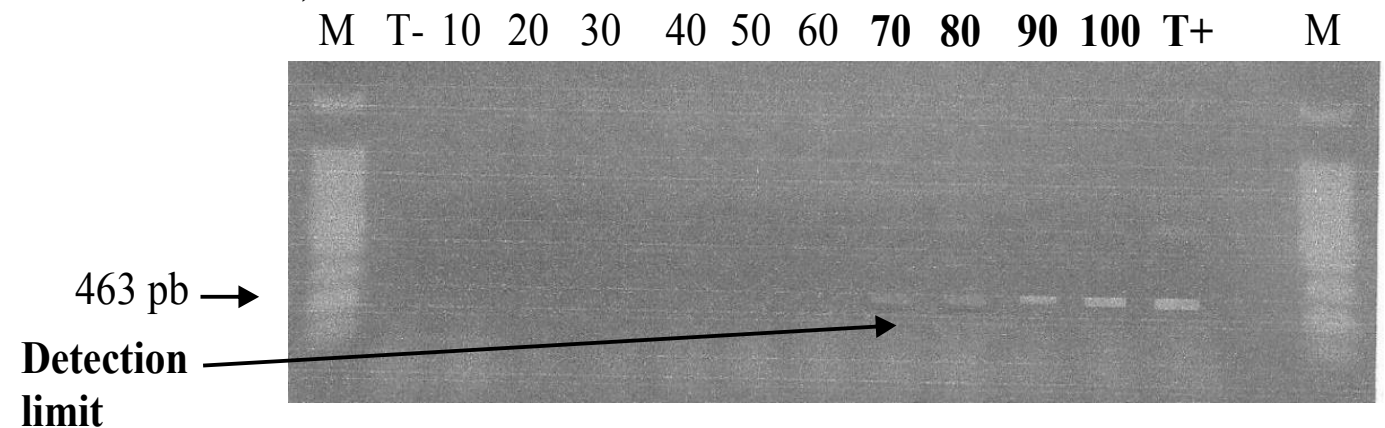

b)

Figure 4. Electrophoresis gels of amplicons for researching molecular detection limit of $F$. oxysporum $\mathrm{f}$. sp. cubense tropical race 4 (Foc TR4). a, DNA of Foc TR4 diluted in ultra-pure water; b, DNA of Foc TR4 mixed with total DNA of free Foc TR4 soil; T+ and T-, positive and negative control; $\mathbf{M}$, size marker; 10 to 100, Quantity (ng) of Foc TR4 DNA in the PCR mix.

pure water and (ii) DNA of Foc TR4 mixed with total DNA of free Foc TR4 soil are presented in the Figure 4. It appears on electrophoresis gels $463 \mathrm{pb}$ amplicons with various intensities depending on DNA of Foc TR4 amount in each mix. Fragment intensities decrease according DNA amount deposited in wells. These fragments are observed for the DNA of Foc TR4 quantity greater than or equal to $33.33 \pm 5.77 \mathrm{ng}$ in the case of DNA of Foc TR4 diluted in ultra-pure water and et $73 \pm 6.02 \mathrm{ng}$ when DNA of Foc TR4 is mixed with total DNA of free Foc TR4 soil. Therefore, DNA of Foc TR4 diluted in ultra-pure water is detected by PCR from $33.33 \pm 5.77 \mathrm{ng}$ whereas at the state mixed with total DNA of free Foc TR4 soil, detection limit is $73 \pm 6.02$ ng.

\section{DISCUSSION}

As there are no effective measures for controlling the soil fungus Foc TR4 responsible for banana Fusarium wilt (Zhang et al., 2013), knowledges about the distribution of this fungus in banana growing areas are necessary to take appropriate measures for a good management of Fusarium wilt in these areas. In this study, Foc TR4 was researched through two detection approaches in the soil of some banana plantations in Côte d'Ivoire. With CDMA, for the 10 samples (S1B1, S2B1, S1B2, S2B4, S1B6, S2B6, S1B7, S2B7, S1B8 and S2B8), 550 bp amplicons generated by amplifying DNA of presumptive $F$. oxysporum with primers ITS $1 /$ ITS 4 , is one of those obtained after amplification of the ITS regions of rDNA in many fungi including Fusarium (Abd-Elsalam et al., 2003; Mohankumar et al., 2010). The amplified ITS sequences of DNA of presumptive $F$. oxysporum contain 485 nucleotides. Alignment statistics $(100 \%$ coverage and similarity for $F$. oxysporum) indicate that these presumptive $F$. oxysporum isolated from soil samples correspond to $F$. oxysporum. Indeed, similarity percentages of at least $99 \%$ between the amplified sequences and those classified in the databases, have been observed by Majid et al. (2015) for the molecular identification of fungi. The distribution of $F$. oxysporum (presence in 10 soil samples out of the 16 analyzed) may be related to (i) its saprophytic nature of agricultural ecosystems and (ii) eventually the multi-culture in the banana plantations investigated. F. oxysporum contains many pathogenic, non-pathogenic and endophytic subspecies (Fravel et al., 2003). The pathogenic subspecies of $F$. oxysporum have a specificity for one or more given plants (Smith, 2007). Hence, this specificity 
increases the rate of soil samples harboring F. oxysporum. The absence of $F$. oxysporum in 6 other soil samples could be the result of a suppressor effect for $F$. oxysporum of soils analyzed or the fact that these soils are naturally free of this micromycete. Indeed, the study of soil fungal diversity of banana plantations in Loh-Djiboua region indicated the frequent occurrence of Trichoderma (Ouina et al., 2020) which produces metabolites that can limit or arrest the development of $F$. oxysporum (Hibar et al., 2005). In $75 \%$ of the banana plantations, the occurrence of $F$. oxysporum in the soil sample in position 1 as well as in sample in position 2 may be related to the movement of spores and mycelial fragments of this micromycete from one zone to another. These spores are disseminated by various vectors including wind, water, insects or human (Aquino et al., 2013). F. oxysporum found in these samples, could thus indicate that the entire extent of investigated banana plantations is infested by this micromycete or exposed to its spread. The $463 \mathrm{bp}$ amplicons obtained with primers Foc TR4-F/Foc TR4-R from DNA of $F$. oxysporum isolated in 8 soil samples S1B1, S2B1, S1B2, S2B4, S1B6, S2B6, S2B8 and S2B8 indicate that these $F$. oxysporum corresponds to Foc TR4 (Dita et al., 2010).

With CIMA, DNA concentrations of 5 to $55 \mathrm{ng} / \mu \mathrm{L}$ for 350 $\mathrm{mg}$ soil collected, so 14.28 to $157.14 \mu \mathrm{g} / \mathrm{g}$ of soil, extracted from these soils are very low in comparison with those extracted from $F$. oxysporum mycelium (231.4 to 577.3 $\mathrm{ng} / \mu \mathrm{L}$ ) for CDMA. This is due to the fact that micromycetes are present in soil samples in the form of spores or their growth is low in these samples as compared to the culture medium where the mycelium is well developed (Smolińska and Kowalczyk, 2014). Other hypotheses are the incomplete rupture of the cell membranes of the microorganisms present in the soil samples or the degradation by DNAses of a certain amount of genomic DNA during the cell lysis step (England and Trevors, 2003; Saeki and Kunito, 2010). The bead beating direct lysis method described here is however more efficient than those used by Yeates et al. (1998) yielded 15 to $23.5 \mu \mathrm{g}$ DNA/g of soil, Mishra et al. (2013) yielded 19.20 to 40.82 $\mu \mathrm{g}$ DNA/g of soil. No amplification with universal and specific primers used in our study was observed with the DNA extracted from the soil sample S2B7 probably because of it has been contaminated by factors such as humic and fulvic acids affecting the PCR reactions. These humic substances containing the same charges and size characteristics as DNA (particularly humic acids), are mostly co-extracted with DNA. They constitute at very low concentrations (10 ng of humic acids), a major source of inhibition of amplification reactions by interfering with the activity of DNA polymerase and the hybridization processes (Matheson et al., 2010; Schrader et al., 2012; Fatima et al., 2014). A 463 pb DNA fragments were obtained from DNA extracted from soil samples S1B2, S1B6 and S2B6.
This size of amplicons characteristic of Foc TR4 (Dita et al., 2010), indicates that the fugus Foc TR4 was found in these soil samples analyzed.

Comparative analysis of the culture-dependent and independent molecular methods, indicated that CDMA allowed to detect Foc TR4 in more soil samples (8 soil samples as opposed to 3 with CIMA). For this culturable micro-organism Foc TR4, cultivation-based method gave a good prediction of its distribution in soil samples. This is observed by Wei et al. (2021) in their work on bacterial community of rhizosphere and bulk soils of Minqin Desert (China). Owing to fail of culturing to reproduce the ecological niches and symbiotic relationships many microorganisms encounter in their natural environments which are required for their survival, the large majority of soil microbes are recalcitrant to culturing techniques (Vieira and Nahas, 2005; Nocker et al., 2007). This makes culture independent approach a good way of exploring a large proportion of microbial population whether they are cultivable or not (Qaisrani et al., 2019). According to our results, there is a large difference in detection sensitivity of Foc TR4 between the direct and indirect methods. CIMA seems the least sensitive for the analyzed soil samples. Although it is quick to perform, it is limited by the quantities and qualities of the extracted DNA, which are respectively weak and poor in comparison with those obtained by the culture-dependent approach.

For the molecular detection threshold of Foc TR4 in CIMA, the decrease of signal intensities in proportion to DNA quantities, observed under each condition would be related to the total number of target regions of Foc TR4F/Foc TR4-R primers in the PCR medium. Thus, an important amount of DNA of Foc TR4 results in amplicons with a high intensity signal. DNA of Foc TR4 diluted in ultra-pure water was detected by PCR from $33.33 \pm 5.77$ ng whereas when mixing with total DNA of free Foc TR4 soil, the detection limit is around $73 \pm 6.02 \mathrm{ng}$. Raoudha et al. (2012) performed amplifications from $10 \mathrm{ng}$ of DNA of leaf plant Stipa lagascae. In our study, the DNA threshold are much higher than the one obtained by Latvala et al. (2019) which is $100 \mathrm{pg}$ of DNA of pathogenic $F$. oxysporum strains in onion harvest. This difference of detection threshold is linked to the dual PCR protocol, the used primers and the two types of DNA (DNA of onion and DNA of pathogenic $F$. oxysporum strains in onion) in the reactional medium that these authors used. The threshold values obtained for the molecular detection of Foc TR4, represent important data for the development of research tools for this fungus.

Combining culture-dependent and culture-independent molecular approaches for searching for Foc TR4 in soil of some banana plantations located in Lakota and Divo, allowed to isolate Foc TR4 in 5 banana plantations out of the 8 investigated. It gave a good idea of the distribution of Foc TR4 and opens up perspectives on the analysis of key factors shaping this distribution in investigated banana 
plantations.

\section{ACKNOWLEDGEMENTS}

This work was supported by the "Ministère des Affaires Etrangères (France) 》 and by the " Ministère de l'Enseignement Supérieur et de la Recherche Scientifique (Côte d'Ivoire) » through doctoral training fellowships.

\section{REFERENCES}

Abd-Elsalam K. A., Aly I. N., Abdel-Satar M. A., Khalil M. S. \& Verreet J. A. (2003). PCR identification of Fusarium genus based on nuclear ribosomal-DNA sequence data. Afr. J. Biotechnol. 2:82-85.

Aquino R. S. S., Silveira S. S., Pessoa W. F. B., Rodrigues A., Andrioli J. L., Delabie J. H. C. \& Fontana R. (2013). Filamentous fungi vectored by ants (Hymenoptera: Formicidae) in a public hospital in northeastern Brazil. J. Hosp. Infect. 83:200-204.

Daly A. \& Walduck G. (2006). Fusarium wilt of bananas (Panama Disease) (Fusarium oxysporum f. sp. cubense). Australia: Department of Primary Industry, Fisheries and Mines, Agnote. No: 151.

De Bellaire L. L., Fouré E., Abadie C. \& Carlier J. (2010). Black leaf streak disease is challenging the banana industry. Fruits. 65:327-342.

Dita M. A., Waalwijk C., Buddenhagen I. W., Souza J. M. T. \& Kema G. H. J. (2010). A molecular diagnostic for tropical race 4 of the banana Fusarium wilt pathogen. Plant. Pathol. 59:348-357.

Dita M., Barquero M., Heck D., Mizubuti E. S. G. \& Staver C. P. (2018). Fusarium wilt of banana: current knowledge on epidemiology and research needs toward sustainable disease management. Front. Plant. Sci. 9: 1468. https://doi.org/10.3389/fpls.2018.01468

Domsch K. H., Gams W. \& Andersen T. H. (1980). Compendium of soil fungi volume 1. England (UK): Academic Press.

Ellis M. L., Jimenez D. R. C., Leandro L. F. \& Munkvold G. P. (2014). Genotypic and phenotypic characterization of fungi in the Fusarium oxysporum species complex from soybean roots. Phytopathol. 104:1329-1339.

England L. S. \& Trevors J. T. (2003). The microbial DNA cycle in soil. Riv Biol. 96:317-326.

Fatima F., Pathak N. \& Verma S. R. (2014). An improved method for soil DNA extraction to study the microbial assortment within rhizospheric region. Mol. Biol. Int. vol. 2014, Article ID 518960. 6p. http://dx.doi.org/10.1155/2014/518960.

FIRCA (2014). The fruit sectors. Newsletter of the interprofessional fund for agricultural research and advice. Abidjan (Côte d'Ivoire). 13: 48

Fravel D., Olivain C. \& Alabouvette C. (2003). Research review Fusarium oxysporum and its biocontrol. New. Phytol. 157:493-502.

Hibar K., Daami-Remadi M., Khiareddine H. \& El-Mahjoub M. (2005). Effet inhibiteur in vitro et in vivo du Trichoderma harzianum sur Fusarium oxysporum f. sp. radices-lycopersici. Biotechnol. Agron. Soc. Envir. 9:163-171.

Kra K. D., Diallo H. A., Kobenan K., Kone D. \& Kouadio Y. J. (2011). Diagnosis of banana Fusarium wilt on banana cultivars "Grand Nain" (Musa AAA) and "Corn 1" (Musa AAB) on the periphery of the district of Abidjan (Côte d'Ivoire). IJBCS. 5:1501-1514.

Lassoudière A. (2007). Banana tree and its culture. Quæ. Paris. 384p.

Latvala S., Haapalainen M., Kivijärvi P., Suojala-Ahlfors T., livonen S. \& Hannukkala A. (2019). Sampling and PCR method for detecting pathogenic Fusarium oxysporum strains in onion harvest. Lett. Appl. Microbiol. 70:210-220.

Lin Y. H., Su C. C., Chao C. P., Chen C. Y., Chang C. J., Huang J. W. \& Chang P. F. L. (2013). A molecular diagnosis method using real-time PCR for quantification and detection of Fusarium oxysporum f. sp. cubense race 4. Eur. J. Plant. Pathol. 135:395-405.

Majid A. H. A., Zahran Z., Rahim A. H. A., Ismail N. A., Rahman W. A., Zubairi K. S. M., Dieng H. \& Satho T. (2015). Morphological and molecular characterization of fungus isolated from tropical bed bugs in Northern Peninsular Malaysia, Cimex hemipterus (Hemiptera: Cimicidae). Asian. Pac. J. Trop. Biomed. 5:707-713.

Matheson C. D., Gurney C., Esau N. \& Lehto R. (2010). Assessing PCR inhibition from humic substances. Open. Enzym. Inhib. J. 3:38-45.

Mishra R. K., Pandey B. K., Muthukumar M., Pathak N. \& Zeeshan M. (2013). Detection of Fusarium wilt pathogens of Psidium guajava L. in soil using culture independent PCR (ciPCR). Saudi J. Biol. Sci. 20:5156. https://doi.org/10.1016/j.sjbs.2012.10.007

Mohankumar M., Vijayasamundeeswari A., Karthikeyan M., Mathiyazhagan S., Paranidharan V. \& Velazhahan R. (2010). Analysis of molecular variability among isolates of Aspergillus flavus by PCRRFLP of the ITS regions of rDNA. J. Plant. Prot. Res. 50:446-451.

Mostert D., Molina A. B., Daniells J., Fourie G., Hermanto C., Chao C-P., Fabregar E., Sinohin V. G., Masdek N., Thangavelu R., Li. C., Yi G., Mostert L. \& Viljoen A. (2017). The distribution and host range of the banana Fusarium wilt fungus, Fusarium oxysporum f. sp. cubense, in Asia. PLoS ONE. 12(7):e0181630. https://doi.org/10.1371/journal.pone.0181630.

Nocker A., Burr M. \& Camper A. K. (2007). Genotypic microbial community profiling: A critical technical review. Microb. Ecol. 54:276 289. DOI: $10.1007 / \mathrm{s} 00248-006-9199-5$.

Ouina T. S., Panoff J. M., Gente S., Garon D., Rioult J. P., Gonnety J. T. \& Koussémon M. (2020). Cropping practices and fungal contamination in banana plantations in Côte d'Ivoire. Res. J. Microbiol. 15:98-108.

Pegg K. G., Moore N. Y. \& Bentley S. (1996). Fusarium wilt of banana in Australia: A review. Aust. J. Agr. Res. 47(5):637-650.

Perez-Vicente L., Dita M. A. \& Martinez-de la Parte E. (2014). Technical manual prevention and diagnostic of Fusarium wilt (Panama disease) of banana caused by Fusarium oxysporum f. sp. cubense Tropical Race 4 (TR4). Rome (Italia): FAO. 74p.

Ploetz R. C. (2000). Panama disease: A classic and destructible disease of banana. Plant Health Prog. 23:1-17. doi: 10.1094/PHP-2000-120401-HM.

Ploetz R. C. (2005). Panama disease: An old nemesis rears its ugly head part 2. The Cavendish era and beyond. Plant Health Prog. 23:1-17. doi: 10.1094/APSnetFeature-2005-1005.

Ploetz R. C. (2015). Fusarium wilt of banana. Phytopathol. 105:15121521.

PRICI (2016). Cadre de gestion environnementale et sociale, Rapport final. PRICl. Abidjan, Côte d'Ivoire. 203p.

Qaisrania M. M., Zaheerb A., Mirz M. S., Naqqash T., Qaisrani T. B., Hanif M. K., Rasool G., Malik K. A., Ullah S., Jamal M. S., Mirza Z., Karim S. \& Rasool M. (2019). A comparative study of bacterial diversity based on culturable and culture-independent techniques in the rhizosphere of maize (Zea mays L.). Saudi J. Biol. Sci. 26:1344-1351. https://doi.org/10.1016/j.sjbs.2019.03.010.

Raoudha A., Amel S., Hassen G. \& Azeiz O. B. (2012). DNA extraction and PCR (Polymorphism Chain Reaction) optimization for RAPD markers application in Stipa lagascae. Acta Bot.Gall. 159:73-78. http://dx.doi.org/10.1080/12538078.2012.671646.

Saeki K. \& Kunito T. (2010). Adsorptions of DNA molecules by soils and variable-charged soil constituents. Current Research, Technology and Education Topics in Applied Microbiology and Microbial Biotechnology. 188-195.

Schrader C., Schielke A., Ellerbroek L. \& Johne R. (2012). PCR inhibitors - occurrence, properties and removal. J. Applied. Microbiol. 113:10141026.

Seguin V., Gente S., Heurté N., Verite P., Kientz-Bouchart V., Sage L., Goux D. \& Garon D. (2014). First report of mycophenolic acid production by Eurotium repens isolated from agricultural and indoor environments. World. Mycotoxin. J. 7:321-328.

Smith S. N. (2007). An overview of ecological and habitat aspects in the genus Fusarium with special emphasis on the soilborne pathogenic forms. Plant. Pathol. Bull. 16:97-120.

Smolińska U. \& Kowalczyk W. (2014). The impact of the Brassicaceae plant materials added to the soil on the population of Fusarium solani (mart.) sacc. and Fusarium oxysporum schlecht. J. Hortic. Res. 22: 123-129.

Stover R. H. (1959). A Rapid and simple pathogenicity test for detecting 
virulent clones of Fusarium oxysporum f. cubense using seedlings of Musa balbisiana. Nature. 184:1591-1592.

Sutherland R., Viljoen A., Myburg A. A. \& van den Berg N. (2013). Pathogenicity associated genes in Fusarium oxysporum f. sp. cubense race 4. S. Afri. J. Sci. 109:1-10.

Vieira F. C. S. \& Nahas E. (2005). Comparison of microbial numbers in soils by using various culture media and temperatures. Microbiol. Res. 160:197-202. doi:10.1016/j.micres.2005.01.004.

Viljoen A. (2002). The status of Fusarium wilt (Panama disease) of banana in South Africa. S. Afr. J. Sci. 98:341-344.

Viljoen A., Mostert D., Chiconela T., Beukes I., Fraser C., Dwyer J., Murray H., Amisse J., Matabuana E. L., Tazan G., Amugoli O. M., Mondjana A., Vaz A., Pretorius A., Bothma S., Rose L. J., Beed F., Dusunceli F., Chao C. P. \& Molina A. (2020). Occurrence and spread of the banana fungus Fusarium oxysporum f. sp. cubense TR4 in Mozambique. S. Afr. J. Sci. 116:11-12. https://doi.org/10.17159/sajs.2020/8608.

Warcup J. H. (1950). The soil-plate method for isolation of fungi from soil. Nature. 166:117-118.

Warman N. M. \& Aitken E. A. B. (2018). The movement of Fusarium oxysporum f. sp. cubense (Sub-Tropical Race 4) in susceptible cultivars of banana. Front. Plant Sci. 9: 1748. https://doi.org/10.3389/fpls.2018.01748.
Wei Y., Wang F., Gao J., Huang Y., Ren W. \& Sheng H. (2021). Culturedependent and culture-independent characterization of bacterial community diversity in different types of sandy lands: the case of Minqin county, China. BMC Microbiol. 21:87. https://doi.org/10.1186/s12866-021-02150-0.

Yao A. K., Koffi D. M., Irié Z. B. \& Niamke S. L. (2014). Conservation of plantain banana (Musa AAB) in the green state by using polyethylene films of different thicknesses. J. Anim. Plant. Sci. 23:3677-3690.

Yeates C., Gillings M. R., Davison A. D., Altavilla N. \& Veal D. A. (1998). Methods for microbial DNA extraction from soil for PCR amplification. Biol. Proced. Online. 1:40-47. doi: 10.1251/bpo6

Zhang M. Z. \& Zhang S. (2011). An efficient DNA extraction method for polymerase chain reaction-based detection of Mycobacterium avium subspecies paratuberculosis in bovine fecal samples. J. Vet. Diagn. Invest. 23:41-48.

Zhang X., Zhang H., Pu J., Qi Y., Yu Q., Xie Y. \& Peng J. (2013). Development of a real-time fluorescence loopmediated isothermal amplification assay for rapid and quantitative detection of Fusarium oxysporumf. sp. cubense tropical race 4 in soil. PLoS ONE. 8: e82841. doi:10.1371/journal.pone.0082841. 